\title{
The circumstances under which section 85(a) of the National Credit Act 34 of 2005 can be utilised as an avenue to access or re- access the debt relief measures in terms of the Act
}

\author{
Stefan Renke \\ BLC LLB LLM LLD (UP) \\ Associate Professor Department of Mercantile Law University of Pretoria \\ Hermie Coetzee \\ BCOM LLB LLM LLD \\ Associate Professor Department of Mercantile Law University of Pretoria
}

\section{OPSOMMING}

Die omstandighede waaronder artikel 85(a) van die Nasionale Kredietwet 34 van 2005 as roete gebruik kan word om toegang of her-toegang tot die skuldverligtingsmaatreëls ingevolge die Wet te bekom

Hierdie artikel neem artikel 85(a) van die Nasionale Kredietwet 34 van 2005 as 'n toegangsroete tot die skuldverligtingsmaatrels waarvoor in Deel $\mathrm{D}$ van Hoofstuk 4 van die Wet voorsiening gemaak word, in oënskou. Dit vind plaas teen die agtergrond van 'n dictum deur Binns-Ward $\mathrm{R}$ in Kallides en die reaksie daarop, onder andere deur die Hoogste Hof van Appèl in Seyffert, deur te ondersoek of daar meerdere opsies is (as wat onder andere deur Binns-Ward R aangedui word) waaronder artikel 85(a) toegang tot die genoemde skuldverligtingsmaatrels verleen. Artikel 85(a) en die howe se diskresie ingevolge daarvan word kortliks toegelig, gevolg deur 'n bespreking van die omstandighede waaronder die verbruiker 'n beroep op artikel 85(a) kan doen. Besondere aandag word aan die wisselwerking tussen artikel 85(a) en artikels 86(2), 86(10) (saamgelees met artikel 86(11)), 88(3) en 83 van die Wet geskenk. Die skrywers maak sekere gevolgtrekkings rakende die trefwydte van artikel 85(a) as die kredietverbruiker se "last port of call" ten einde die skuldverligting ingevolge die Wet te bekom.

\section{Introduction}

Much has been written on the various debt relief measures (and their advantages, disadvantages and effectiveness or lack thereof) available in law to South African debtors. ${ }^{1}$ These include the debt relief measures

1 See inter alia Boraine and Roestoff "Revisiting the state of consumer insolvency in South Africa after twenty years: The courts' approach, international guidelines and an appeal for urgent law reform" (part 1) 2014 THRHR 351 and (part 2) 2014 THRHR 527 and Coetzee "Is the unequal

How to cite: Renke \& Coetzee 'The circumstances under which section 85(a) of the National Credit Act 34 of 
introduced by the National Credit $A c t,{ }^{2}$ the consumer credit legislation currently in force in South Africa. A core aim of the NCA is to protect consumers by providing mechanisms for resolving over-indebtedness ${ }^{3}$ and for the first time in the history of South African consumer credit legislation it provides for the debt relief of over-indebted credit consumers. ${ }^{4}$ The main debt relief measures in terms of the Act are provided for in sections 83(3) and 86(7)(c)(ii) read with section 87(1)(b) ${ }^{5}$ and naturally are applicable only if the particular credit agreement concluded by the consumer falls within the ambit of the Act. ${ }^{6}$

A consumer is afforded various routes to access the NCA's debt relief measures. One route is that a consumer may apply to a debt counsellor to be declared over-indebted and to be placed under debt review. ${ }^{7}$ This route is called "voluntary debt review". 8 Also, debt relief may follow in a case where during any court or National Consumer Tribunal ${ }^{9}$ proceedings the court or the Tribunal mero motu takes cognisance of the fact that a credit agreement is reckless and declares it to be so. ${ }^{10}$ If entering into the particular credit agreement caused the consumer's over-indebtedness, ${ }^{11}$ the court or the Tribunal will exercise its powers in terms of section 83(3)(b)(i) and (ii) to provide relief to the consumer provided that the consumer is still over-indebted at the time of the court or Tribunal proceedings. ${ }^{12}$ Finally, a consumer may avail him- or herself of section 85 to obtain debt relief by alleging in any court proceedings in which a credit agreement is being considered that he or she is overindebted.

treatment of debtors in natural person insolvency law justifiable?: A South African exposition" 2016 Int Insolv Rev 36.

234 of 2005 (hereafter "the NCA" or "the Act").

3 See Roestoff "The objective of providing debt relief to over-indebted consumers and the interpretation of section 85 of the National Credit Act Firstrand Bank Ltd v Govender [2014] JOL 31572 (ECP)" 2015 THRHR 694 696, 701-703 and s 3(g) and (i). See s 79 for the definition of "overindebtedness".

4 In Ch 4 Part D. These measures are not available to so-called "juristic person" consumers - s 78(1). See s 1 for the definition of "juristic person" in terms of the Act.

5 See Van Heerden in Scholtz (ed) Guide to the National Credit Act (2008) paras 11.3.3.1, 11.3.3.2 (j)(iii) and (l), 11.5.7 and 11.5.7.2 and Coetzee $A$ comparative re-appraisal of debt relief measures for natural person debtors in South Africa, LLD thesis, UP (2015) 189-235 and 258-269 for an exposition of these measures.

6 For a full exposition of the latter, see Kelly-Louw assisted by Stoop Consumer Credit Regulation in South Africa (2012) 27-94; Van Zyl and Otto in Scholtz (ed) chs 4 and 8 respectively and Otto and Otto The National Credit Act Explained (2016) ch 3.

7 S 86(1).

8 Van Heerden "Section 85 of the National Credit Act 34 of 2005: thoughts on its scope and nature" 2013 De Jure 968, inter alia 971.

9 Hereafter "the Tribunal", established in terms of s 26 of the NCA.

10 In terms of s 83(1). S 25 of the National Credit Amendment Act 19 of 2014 (hereafter "the Amendment Act") amended s 83 to include the Tribunal.

11 And therefore constitutes reckless lending in terms of $\mathrm{s} 80$ (1)(b)(ii).

12 S 83(3)(a) and (b)). 
The aim in this article is to discuss the circumstances under which section 85 can be utilised by the credit consumer as an avenue to access or re-access the NCA's debt relief measures. This exercise has been undertaken in light of Binns-Ward J's and Van Heerden's restrictive interpretation of section 85 in the latter respect. ${ }^{13}$ As well, it is consequent on the Supreme Court of Appeal's remarks subsequent to Kallides in Seyffert and Another $v$ Firstrand Bank t/a First National Bank. ${ }^{14}$ Our further aim is to indicate that section 85 has a broader application than indicated by Binns-Ward $\mathrm{J}$ in Kallides and by Van Heerden.

As indicated below ${ }^{15}$ section 85 in most instances serves as a final opportunity for a credit consumer subject to the NCA to access or reaccess the debt relief measures in terms of the Act. Therefore, from a debt-relief perspective and having regard to the core aim of the NCA referred to earlier the extent of the ambit of the section 85 avenue to debt relief is of cardinal importance. ${ }^{16}$

With the aforementioned aims in mind the provisions of section 85 are discussed briefly ${ }^{17}$ followed by a discussion of the circumstances under which the section can be invoked. ${ }^{18}$ The note ends with our conclusions and final remarks. ${ }^{19}$

\section{Section 85 of the NCA}

Section 85 of the NCA, which resorts under Chapter 4 "Consumer Credit Policy" and more in particular Part D "Over-indebtedness and reckless credit", provides as follows: ${ }^{20}$

"Despite any provision of law or agreement to the contrary, in any court proceedings in which a credit agreement is being considered, if it is alleged that the consumer under a credit agreement is over-indebted, the court may -

(a) refer the matter directly to a debt counsellor with a request that the debt counsellor evaluate the consumer's circumstances and make a recommendation to the court in terms of section 86(7); or

13 In Standard Bank Ltd v Kallides (1061/2012) [2012] ZAWCHC 38 (2 May 2012) SAFLII, available at http://www.saflii.org/za/cases/ZAWCHC/2012/ 38.html (accessed 2018-03-01) and 2013 De Jure respectively. See further par 3 below.

1420126 SA 581 (SCA). See further par 3 below.

15 See par 3.

16 See also Kreuser "The Application of section 85 of the National Credit Act in an application for summary judgment" 2012 De Jure 121 and Roestoff 2015 THRHR 694711.

17 Par 2 below.

18 Par 3 below.

19 Par 4 below.

20 For discussions of s 85 see Kreuser 2012 De Jure 1 et seq; Van Heerden 2013 De Jure 968 et seq; and Roestoff 2015 THRHR 694 et seq. See also Van Heerden in Scholtz (ed) par 11 3.3.5 and Kelly-Louw assisted by Stoop 382392. 
(b) declare that the consumer is over-indebted, as determined in accordance with this Part, and make any order contemplated in section 87 to relieve the consumer's over-indebtedness."

When considering section 85(a) and (b) it is clear, upon an allegation in court proceedings in which a credit agreement is being considered that the consumer is over-indebted, that the court may elect to follow one of two routes. The court may refer the matter directly to a debt counsellor in terms of section 85(a) to evaluate the consumer's circumstances and make one of the recommendations referred to in section $86(7)(\mathrm{a})-(\mathrm{c})^{21}$ or it may in terms of section 85(b) declare that the consumer is overindebted and make any order contemplated in section 87 to relieve the consumer's over-indebtedness. It is submitted that the use of the word "may" gives the court discretion, upon an allegation that the consumer is over-indebted and subject to what is discussed below, to follow a section $85(\mathrm{a})$ or (b) route. However, depending on the debt counsellor's recommendation in terms of section $85(\mathrm{a})$, both routes eventually lead to the debt-relief measures in terms of section $87(1)$ (b) read with section 86(7)(c)(ii).

Thus far no judgment has been reported of a case where a court has relied on the provisions of section 85(b) directly to declare the consumer over-indebted and to make an order as contemplated in section 87 . This lack could be attributed to the fact that most matters involve various credit agreements and that an investigation into a consumer's financial affairs, negotiations with credit providers and the arithmetic involved in such endeavours rather should be left to debt counsellors whose core business involves such functions as opposed to the courts who have a judicial role to fulfil. ${ }^{22}$ Our further discussion consequently focuses on the provisions of section 85(a).

The court's discretion in terms of section 85 further entails that it may refrain from applying either section 85 (a) or (b) ${ }^{23}$ The court could, for instance, decide to grant summary judgment against the consumer. It is evident from the introductory wording to section 85 that two basic prerequisites or "jurisdictional facts" 24 should be met before a court may exercise its discretion in terms of the section. The first is that a credit agreement to which the NCA applies should be under consideration in any court proceedings ${ }^{25}$ and the second is that the consumer's over-

21 Respectively that the consumer is not over-indebted, that the consumer is not over-indebted, but nevertheless is experiencing, or is likely to experience, difficulty in satisfying all the consumer's obligations under credit agreements in a timely manner or that the consumer is overindebted.

22 See below.

23 See below.

24 See Roestoff 2015 THRHR 694698.

25 Action or application proceedings in the High or Magistrate's Court - see Standard Bank of South Africa Ltd v Panayiotts 20093 SA 363 (W) $367-368$. 
indebtedness should be alleged. ${ }^{26}$

Although consumers mostly make use of the section 85 route once enforcement proceedings have been instituted and may do so in a pleading, affidavit or even viva voce, ${ }^{27}$ there seems to be no objection to the consumer invoking the section by means of a substantive application. ${ }^{28}$ However, as the more economical access to debt review in terms of section 86 is still available to a consumer before a credit provider has taken steps to enforce a credit agreement, it is highly unlikely that such a consumer will bring a court application in order to draw his or her situation within the ambit of section 85. A call on the section 85 provisions does not amount to a defence of a claim and usually takes the form of a request to the court to exercise its powers in terms thereof. 29

As an allegation of over-indebtedness is the second prerequisite, the court in Firstrand Bank Ltd $v$ Maleke ${ }^{30}$ acknowledged that it cannot suo motu exercise its powers if no allegation has been made. However, a court may act suo motu if the two statutory prerequisites are present. ${ }^{31}$

As far as the court's discretion in terms of section 85 to refrain from applying section 85(a) is concerned, according to the Supreme Court of Appeal in Seyffert ${ }^{32}$ the fact that a discretion exists is indicated by the word "may" and by the introductory words of section 85, namely, "Despite any provision of law or agreement to the contrary". However, the court, with reference to the Hales judgment, ${ }^{33}$ further stated that before a court may exercise its discretion in terms of section 85 the material facts relied upon must be placed before it. ${ }^{34}$ It further held that a court should be slow to exercise its discretion where the matter has already been dealt with by a debt counsellor or where a debt review has been duly terminated and where no material change in the debtor's circumstances can be shown. 35

The courts' section 85 discretion should be exercised judiciously ${ }^{36}$ and with due regard to the objectives of the NCA as set out in section 3 and other sections which are intended to provide a backdrop against which

\footnotetext{
26 Panayiotts 367.

27 Kallides par 6.

28 Van Heerden 2013 De Jure 968978.

29 Standard Bank of South A frica Ltd $v$ Hales 20093 SA 315 (D) 320; and Collett $v$ Firstrand Bank Ltd 20114 SA 508 (SCA) 518. For a discussion of Hales see Van Heerden and Lötz "Over-indebtedness and discretion of court to refer to debt counsellor: Standard Bank Ltd v Hales 20093 SA 315 (D)" 2010 THRHR 502 et seq.

3020101 SA 143 (GSJ). See also Panayiotts 368.

31 Kallides par 6.

32 Par 15.

33 Paras 12-13.

34 Par 15

35 Par 15.

36 See Hales 321. See also Panayiotts 372 and Andrews v Nedbank Ltd 20123 SA 82 (ECG) 87.
} 
the discretion must be exercised. ${ }^{37}$ The fact that a court must exercise its discretion judiciously means that it should be exercised for substantial reasons and on the material before it and not capriciously on the basis of conjecture or speculation or upon wrong principle. ${ }^{38}$ Therefore, though section 85(a) does not necessitate proof of over-indebtedness, attention should be paid to Hales, ${ }^{39}$ where it was held that the fact of overindebtedness as opposed to an allegation thereof should be taken into account when the court exercises its discretion.

In Panayiotts ${ }^{40}$ it was held that over-indebtedness should be established on a balance of probabilities. Accordingly, a consumer requesting the court to exercise its discretion in terms of section 85 should place as much as possible relevant material before the court to assist it to exercise its discretion judiciously and to make sure that the consumer is not raising his or her over-indebtedness to institute delay with no real intention or probable prospect of obtaining debt relief and eventually satisfying his or her obligations. ${ }^{41}$

According to Van Heerden ${ }^{42}$ in the absence of abuse, the possibility of an economically feasible restructuring is of utmost importance in the court's exercise of its discretion in terms of section 85(a). In conclusion, the courts require a consumer to satisfy the court of a basket full of factors before it will exercise its section 85(a) discretion in favour of the consumer and refer the matter to a debt counsellor. ${ }^{43}$

\section{The Circumstances Under Which Section 85 May be Invoked}

\section{Introduction}

Although the wording of section 85 is cast in very wide terms, requiring only the jurisdictional facts ${ }^{44}$ to be present as condition for its invocation, the question arises whether the section may be invoked under all circumstances in which the jurisdictional facts are present. In this regard the following dictum by Binns-Ward $\mathrm{J}$ in the Kallides judgment ${ }^{45}$ is relevant:

37 See Hales 321; Firstrand Bank Ltd v Olivier 20093 SA 353 (SE) 359; and Andrews 87.

38 See Hales 321 where the court refers to Myburgh Transport $v$ Botha 19913 SA 310 (Nms) 314 and First National Bank of SA Ltd v Myburg 2002 4 SA 176 (C) 184 .

39322.

40368 and 373.

41 See Hales 321

422013 De Jure 968990.

43 See the discussion of such requirements by Van Heerden 2013 De Jure 968 989-990.

44 See par 2 above.

45 Par 8. 
"Notwithstanding the breadth of the opening words to s 85 of the NCA, reference to the broader context of the statute impels the conclusion that the section was not intended to provide a basis for a repetition of the process already provided for in terms of $\mathrm{s} 86$, or to draw back within the ambit of debt review debts already excluded therefrom by the operation of other provisions of the Act, such as s 86(2), s 86(10) or s 88(3). To construe s 85 otherwise would be conducive to the most unwholesome circularity, at odds with basic principle - interest rei publicae ut sit finis litium" (loosely translated as "it is in the interest of the state that legislation be finalised" - Hiemstra and Gonin Drietalige Regswoordeboek 3rd ed (2005) 211).

Therefore, in considering the circumstances for which section 85 was intended and in light of the above dictum of Binns-Ward J, the provisions of sections 86(2), 86(10) (read with s 86(11)) and 88(3) and the interrelation between these sections and section 85 are important. The same holds for the fact that the Supreme Court of Appeal in Seyffert ${ }^{46}$ referred to the conclusion by Binns-Ward J and made a (qualified) remark that it is too absolute and loses sight of the court's discretion as provided for by the words "may" and "Despite any provision of law or agreement to the contrary" in the introductory words of section 85. The interrelation between section 85 and the aforementioned sections now will be discussed and followed by a brief discussion of the interplay between sections 83 and $85 .{ }^{47}$

\section{Section 86(2) NCA}

Reference has been made to the fact that a consumer can access the NCA's debt relief measures in terms of section 86(1) by applying to a debt counsellor to be declared over-indebted and to be placed under debt review. ${ }^{48}$ Section $86(2)$ embodies the principle that debt review and debt enforcement in court ${ }^{49}$ can never take place at the same time. Section 86(2) provides that a particular credit agreement, in terms of which the credit provider "has proceeded to take the steps contemplated in section 130 to enforce that agreement", is excluded from a section 86(1) application for debt review.

Van Heerden ${ }^{50}$ refers to the situation in which the consumer did not previously apply for the debt review procedure in terms of section 86(1) as a scenario where a consumer might be interested in invoking section 85 post-enforcement. ${ }^{51}$ She is of the opinion that it could not have been

46 587. See Steyn "Firstrand Bank Ltd t/a First National Bank $v$ Seyffert and three similar cases 20106 SA 429 (GSJ), Seyffert \& Seyffert $v$ Firstrand Bank Ltd 2012 ZASCA 81: Bringing home the inadequacies of the National Credit Act 34 of 2005" 2012 De Jure 639 et seq for a discussion of the judgments of both the court a quo and the Supreme Court of Appeal in the context of the NCA's inability adequately to address issues pertaining to the execution against debtors' mortgaged homes.

47 Although s 83 is not mentioned by Binns-Ward $\mathrm{J}$ in his dictum.

48 See par 1 above.

49 In terms of Part $\mathrm{C}$ of $\mathrm{Ch} 6$ of the Act.

502013 De Jure 968973.

51 The other two scenarios are discussed in par 33 below. 
the intention of the legislature that section 86(2) bars a consumer from utilising section 85 in an attempt to access the debt-review process for the first time and therefore does not agree with Binns-Ward J that a debtor who was precluded by section 86(2) from applying for the debt review process upon delivery of the section 129(1)(a) NCA notice cannot use section 85 to access debt review for the first time. ${ }^{52}$ Van Heerden submits that in considering the legislature's lenient approach to debt review, ${ }^{53}$ "it could not have been the legislature's intention to provide such a small window of opportunity [to apply for debt review]", to wit the period before the delivery of the section 129(1)(a) notice, which often is brief. 54

We submit that Van Heerden is correct in contending that it could not have been the intention of the legislature to exclude, in all instances, credit agreements from a possible debt re-arrangement where debt enforcement has commenced. We further submit that this situation could have been the exact circumstances that the legislature had in mind when drafting section 85 . The legislature could have intended that credit agreements where enforcement has commenced should be excluded from debt review as a matter of course, ${ }^{55}$ but that such agreements may be subjected to the debt review process at the discretion of a court in terms of section 85 where the circumstances and rationality necessitate such inclusion. Binns-Ward $J$ indeed referred to the fact that the processes in terms of sections 85 and 86, although they are to be contrasted, have similar objectives, namely, to obtain the consideration of the circumstances and recommendation by a debt counsellor and/or the drawing of a debt-relief order. 56

Further, should one accept that Binns-Ward J was correct in permanently excluding credit agreements where enforcement proceedings have commenced there would be very few situations in which a bona fide consumer is able to make use of the section 85 route to access debt relief. Even though section 86(2) has been amended, the time period within which to access debt review in terms of section 86(1)

52 Van Heerden 2013 De Jure 968 977. At the stage when Van Heerden's article was published, in terms of $\mathrm{s} 86(2)$ the delivery of the preenforcement notice in terms of s 129(1)(a) barred an application for debt review. However, s 86(2) subsequently has been amended in terms of s 26(a) of the Amendment Act, resulting in the credit provider under the credit agreement taking the steps contemplated in s 130 to enforce that agreement (issue or service of summons) now barring the consumer from applying for debt review.

53 Inter alia evidenced by the s 86(1) and 86(11) provisions, respectively allowing for voluntary debt review applications and the resumption of debt review after its termination in terms of $\mathrm{s} 86(10)$.

542013 De Jure 968 977. Now, after the amendment of s 86(2), it will be the period before the credit provider has proceeded with the s 130 steps to enforce the credit agreement and not the delivery of the s 129(1)(a) notice which is pertinent.

55 Through the s 86(2) provision.

56 Par 8. 
still is very short. ${ }^{57}$ Where a consumer avails him- or herself of the debt review process for the first time in terms of section 85 there is no circularity present in the sense referred to by Binns-Ward J. We submit that in the instance where a consumer makes use of section 85 to access debt review for the first time the balancing factor is the court's discretion to refrain from applying the provisions of section $85(\mathrm{a}) .^{58}$

\section{Section 86(10) Read With Section 86(11) NCA}

It has been mentioned above ${ }^{59}$ that debt review and debt enforcement cannot subsist at the same time. Section 86(10) creates an avenue for a credit provider to enforce a credit agreement that is subject to debt review. It provides that if a consumer is in default in terms of a credit agreement that is subject to debt review in terms of section 86 the credit provider may give notice to terminate the debt review in the prescribed manner, ${ }^{60}$ provided that at least 60 business days have expired after the date on which the consumer applied for the debt review. ${ }^{61}$ The implication is that such a credit provider may then proceed to enforce the credit agreement due to the fact that it is no longer subject to debt review. Section 86(10) must be read in conjunction with section 86(11). In terms of the latter, if the credit provider who has given notice in terms of section 86(10) to terminate the debt review proceeds to enforce the credit agreement, the court hearing the matter may order that the debt review resume. ${ }^{62}$

In Kallides, which concerned an application for summary judgment, an application was "purportedly" made by the defendant in terms of section $85 .{ }^{63}$ In brief, the debt in respect of which the plaintiff sought to extract payment had been the subject of debt review in terms of section 86. The defendant did not challenge the allegation that the plaintiff terminated the debt review in terms of section 86(10). ${ }^{64}$ Binns-Ward J

57 In particular under circumstances where the credit provider or its legal representative has caused the two time periods of 20 and 10 business days (as defined in $\mathrm{s} 2(5)$ ) provided for in terms of $\mathrm{s}$ 130(1)(a) to run concurrently by delivering the s 129(1)(a) notice soon after default by the consumer has occurred. The default by the consumer and the delivery of the s 129(1)(a) notice respectively trigger the 20 and the 10 business days to run. See Van Heerden in Scholtz (ed) par 12.4.3.

58 Or s 85(b). See par 2 above. See also Kallides par 7, where it was remarked that the failure by a consumer to avail him- or herself of the provisions of $s$ 86 is one of the factors that a court will take into account when deciding whether or not to act in terms of s 85.

59 Par 32.

60 There are no further prescriptions other than those contained in s 86(10).

61 S 86(10)(a). Notice of termination has to be provided to the consumer, the debt counsellor and to the National Credit Regulator. Once the application for debt review has been filed in court (or the Tribunal), the credit provider is barred from terminating the debt review: S 86(10)(b).

62 Subject to the conditions that the court deems just in the circumstances.

63 Par 4.

64 Par 10. 
held that the circumstances in Kallides were such as to exclude the application of section 85.65

However, the defendant was not remediless as section 86(11) provides redress. As regards the latter, Binns-Ward J contended that a consumer has to make an application in terms of section 86(11) in order to invoke its provisions and proceeded to treat the application purportedly made in terms of section 85 as one in substance made in terms of section 86(11). ${ }^{66}$ Accordingly, it was ordered in terms of section 86(11) that the defendant's debt review be resumed, subject to the right of any of the defendant's credit providers to terminate the debt review in terms of section $86(10){ }^{67}$

Seyffert concerned an appeal against an order of the High Court granting summary judgment against the appellants in a case that involved a credit agreement falling under the NCA. ${ }^{68}$ The proceedings in terms of which summary judgment was granted were preceded by an application for debt review by the appellants, which review subsequently was terminated in terms of section $86(10)$ by the credit provider, the respondent in casu. ${ }^{69}$

The appellants argued that the High Court should have exercised its discretion in their favour by acting in terms of either section 85 or section 87 and referring the matter to a debt counsellor or declaring them overindebted and rearranging their repayments. It was submitted that the respondent had not acted in good faith by terminating the debt review. ${ }^{70}$ The Supreme Court of Appeal ${ }^{71}$ thereupon referred to paragraphs from Collett $^{72}$ in which inter alia it was stated that (a) court-ordered debt review in terms of section 85 cannot be terminated by the credit provider; (b) a credit provider's right to terminate debt review proceedings in terms of section 86(10) is balanced by section 86(11); and (c) sufficient information on which the request for debt resumption in terms of the latter sub-section is based must be placed before the court. In Seyffert the appellants neither applied for the resumption of debt review nor demonstrated any basis upon which the respondent was not entitled to terminate the debt review. The restructuring proposals of the appellants were "devoid of economic reality" and a substantial part of their debt would have been left unpaid. ${ }^{73}$

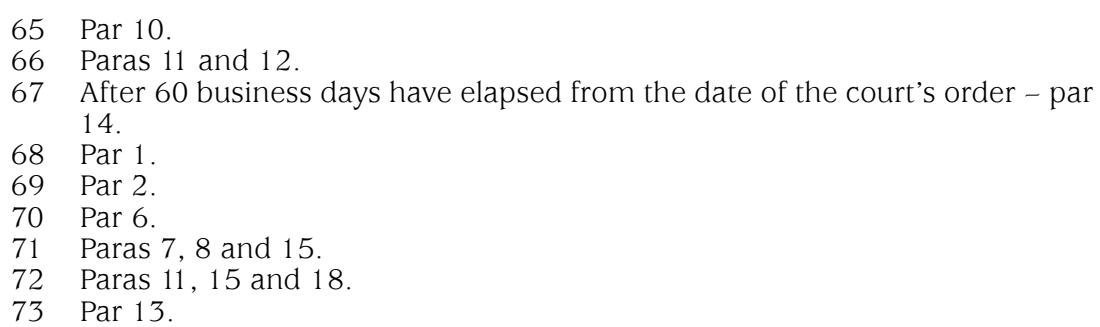


Next, as mentioned above ${ }^{74}$ reference was made to Binns-Ward's J dictum in Kallides, where after the Supreme Court of Appeal made its own qualified remarks. ${ }^{75}$ The court in Seyffert held that the respondent was entitled in law to terminate the debt review and, on the facts, justifiably did so. It also found that this was not a case where debt review could usefully be employed and therefore dismissed the appeal with costs. ${ }^{76}$

The other two scenarios in which according to Van Heerden ${ }^{77}$ a consumer might be interested in invoking section 85 post-enforcement ${ }^{78}$ relate to section 86(10). One is where the consumer did apply for the debt review procedure but the credit provider proceeded with enforcement without terminating the debt review as provided for in section $86(10){ }^{79}$ The other is where a debt review procedure has been terminated in accordance with section 86(10) but the credit provider did not act in good faith. ${ }^{80}$ Van Heerden ${ }^{81}$ submits that in these two scenarios the NCA provides specific procedures other than section 85 that an aggrieved consumer may utilise.

Where the credit provider has failed to terminate a pending debt review prior to enforcement, as is provided for by section 86(10), and then proceeds to enforce the agreement Van Heerden ${ }^{82}$ submits that section 130(4)(c) provides the proper remedy and that section 85 is not suited to such instances. Section 130(4)(c) inter alia provides that the court may adjourn the matter pending a final determination of the debt review proceedings or that the court may order the debt counsellor to report directly to the court and thereafter make an order contemplated in section 85(b), in other words an order in terms of section 87 , to relieve the consumer's over-indebtedness.

In respect of a third scenario where the credit provider makes use of the section 86(10) procedure to terminate the debt review but did not do so in good faith, Van Heerden ${ }^{83}$ argues that section 86(11) provides the suitable remedy, that this remedy is distinct from section 85 in its purposes and that section 85 therefore is not applicable.

Finally, Van Heerden ${ }^{84}$ submits that the dictum by Binns-Ward J is correct

"insofar as it indicates that the legislature did not intend to provide a repetition of the process already provided for in section 86 or to draw back

$74 \quad$ Par 31.

75 Par 15

76 Paras 16 and 17.

772013 De Jure 968973.

78 The first scenario has been discussed in par 32 above.

79 Scenario 2.

80 Scenario 3.

812013 De Jure 968 973-976.

822013 De Jure 968 974-975.

832013 De Jure 968 973-974.

842013 De Jure 968 976-977. 
into the ambit of debt review debts already excluded therefrom by section 86(10) (for which section 86(11) is the appropriate remedy) ..."

We agree with Van Heerden's interpretation of the Act that the court should employ the provisions of section 130(4)(c) where a consumer has applied for debt review in terms of section 86(1) but where the credit provider did not duly terminate the debt review prior to commencing debt enforcement. However, we disagree with Van Heerden's contention that the dictum by Binns-Ward $J$ is correct as far as section 86(10) is concerned and that section 86(11) is the appropriate remedy in the case of a termination of debt review in terms of the former sub-section to the exclusion of section 85. The same objection holds for the interpretation by the courts in Kallides and Seyffert of section 86(11) as being the only counter-measure for a section 86(10) termination once again to the exclusion of section 85 .

It is obvious that section $86(10)$ is balanced by section $86(11)$. Section $86(11)$ empowers the court hearing the matter ${ }^{85}$ to order that debt review resume under circumstances where a credit provider who has given notice in terms of section 86(10) to terminate a review proceeds to enforce that particular credit agreement. The use of "may" in the wording of section 86(11) indicates that the enforcing court has discretion whether or not to order the resumption of debt review. However, in considering the wording of section 86(11) no mention is made of the fact that the consumer must apply to the enforcing court that debt review be resumed. Therefore, the implication is that in terms of section 86(11) a court mero motu may order the resumption of debt review. ${ }^{86}$ However, where that is not done the consumer must be given the opportunity to apply to the enforcing court that his or her debt review be resumed. 87

We submit that the only machinery in the Act providing for an application by the consumer that debt review be resumed is provided for in section 85 . By making use of the latter provision the consumer may allege before the enforcing court in which a credit agreement is being considered that he or she is over-indebted. The consumer thereupon will have to place sufficient information before the court in order to enable it to exercise its discretion in terms of section 85(a) whether or not to refer the matter to a debt counsellor for the latter's recommendation. 88

85 The "enforcing court" - Seyffert par 8.

86 See also Van Heerden in Scholtz (ed) par 11.3.3.4 holding the same opinion because, according to her, s 86(11) does not require the consumer to bring a substantive application.

87 See also Van Heerden in Scholtz (ed) par 11.3.3.4, who submits that upon the termination of a debt review in terms of $\mathrm{s} 86(10)$, the debt counsellor becomes functus officio and that "[w]here a consumer thus requires a resumption of a debt review it appears that it is the consumer who should make the request to the court ...".

88 In Seyffert (par 8) with reference to Collett (par 18) the Supreme Court of Appeal stated that sufficient information on which the request for debt resumption in terms of s 86(11) is based, must be placed before the court. 
Accordingly, we submit that where an enforcing court does not mero motu order that debt review be resumed section 86(11) must be read with section 85. We further submit that Binns-Ward J in Kallides could have achieved the same result by employing section 85 instead of section 86(11). This response would have been "conducive to circularity", but such circularity would have been no less "unwholesome" than the circularity achieved by means of Binns-Ward J's orders.

In addition to the above arguments, if a credit provider terminates debt review in respect of a particular credit agreement in terms of section 86(10) and, therefore, excludes that agreement from the debt review process but thereafter fails to enforce that credit agreement, the resumption of debt review in respect of that agreement in terms of section 86(11) is not an option. We submit that in such an instance the only viable option for the consumer in order to attempt to re-subject the credit agreement to debt review will be to invoke the provisions of section 85 by means of a substantive application.

\section{Section 88(3)}

Section 88(3) is concerned with a credit provider's prohibited conduct once he or she has received notice of court proceedings as contemplated in sections $83^{89}$ or $85^{90}$ or a notice in terms of section $86(4)(\mathrm{b})(\mathrm{i}) .^{91}$ Section 88(3) is subject to section $86(9)^{92}$ and (10) and provides that such a credit provider may not exercise or enforce by litigation or other judicial process any right or security under such an agreement. The prohibition against debt enforcement remains in force until the consumer is in default under that credit agreement ${ }^{93}$ and one of the following has occurred: (a) the debt counsellor has rejected the consumer's application for debt review and the consumer has failed to file directly for debt review to the court in terms of section 86(9) within the prescribed time limit; ${ }^{94}$ (b) the court has determined that the consumer is not over-indebted or has rejected either the debt counsellor's proposal that the consumer is over-indebted or the consumer's direct application for debt review in terms of section 86(9); ${ }^{95}$

89 This notice relates to a declaration by the court or the Tribunal that a credit agreement is reckless.

90 In this instance court-ordered debt review is pertinent.

91 The s 86(4)(b)(i) notice is utilised by a debt counsellor to inform the particular consumer's credit providers of the application for debt review in terms of $\mathrm{s} 86(1)$.

92 Providing that where the debt counsellor rejects the consumer's application for debt review in terms of s 86(1) due to the reasonable conclusion that the consumer is not over-indebted, the latter, with leave of the Magistrate's Court, may apply directly to that court to obtain the necessary relief.

93 The credit agreement that has been declared reckless or that is subject to debt review - s 88(3)(a).

$94 \mathrm{~S} 88(3)(\mathrm{b})(\mathrm{i})$ read with $\mathrm{s} 88(1)(\mathrm{a})$. See reg 26 of the National Credit Regulations (GN R489 in GG 28864 of 31 May 2006) for the prescribed time limit.

95 S 88(3)(b)(i) read with s 88(1)(b). 
(c) a court has re-arranged ${ }^{96}$ the consumer's obligations ${ }^{97}$ and all the consumer's obligations under the credit agreements are fulfilled; ${ }^{98}$ or (d) the consumer defaults on any obligation in terms of a re-arrangement as ordered by a court or the Tribunal. ${ }^{99}$

Section 88 promotes the debt relief objectives of section 85 in that it creates a moratorium on debt enforcement to allow time for a possible solution to the consumer's over-indebtedness to be found. Also, section 88 is directed at the prevention of further indebtedness as section 88(1) provides that a consumer who has alleged in court that he or she is overindebted ${ }^{100}$ must not incur any further charges under a credit facility ${ }^{101}$ or enter into any further credit agreement, other than a consolidation agreement.

However, with reference to the provisions of section 88(3), the conclusion by Binns-Ward J that section 85 was not intended "to draw back within the ambit of debt review debts already excluded therefrom by the operation of ... s 88(3)" and that "[t]o construe s 85 otherwise would be conducive to the most unwholesome circularity" seems to be correct.

Nevertheless, there could be exceptional circumstances in which this is not the case, for instance where the consumer has applied for debt review in terms of section 86 and the debt counsellor has notified the consumer's credit providers of the debt review application in terms of section 86(4)(b)(i). The receipt of the notice bars a credit provider in terms of section 88(3) from enforcing in court a credit agreement which is subject to debt review. The bar against debt enforcement comes to an end, for instance, if the consumer is in default in terms of the credit agreement, the debt counsellor has rejected the consumer's application for debt review and the consumer has failed to file directly for debt

96 In terms of s 86(7)(c)(ii).

97 Or the consumer and his or her credit providers have made an agreement re-arranging the consumer's obligations.

$98 \mathrm{~S} 88(3)(\mathrm{b})$ (i) read with $\mathrm{s}$ 88(1)(c). The exception is where the consumer fulfilled the obligations by means of a consolidation agreement. The concept "consolidation agreement" is not defined in the NCA. However, it is submitted that a consolidation agreement is an agreement in terms of which a consumer's existing debt is consolidated under one agreement. See also reg 23A(14) which refers to "a credit agreement [that] is entered into on a substitutionary basis in order to settle off one or more credit agreement". If the consumer fulfils obligations by means of a consolidation agreement, the bar against debt enforcement should subsist until all the consumer's obligations in terms of the original (or subsequent) consolidation agreement/s have been fulfilled. S 88(2) provides for consecutive consolidation agreements.

99 Or as agreed upon between the consumer and his or her credit providers s 88(3)(b)(ii).

100 In terms of $\mathrm{s} 85$.

101 As defined in s 8(3) of the Act. 
review to the court in terms of section 86(9) within the prescribed time limit. ${ }^{102}$ If the credit provider continues to enforce, the consumer should be permitted to avail him- or herself of the provisions of section 85 to allege over-indebtedness and to explain to the court why the section 86(9) application for debt review was not filed in time.

Therefore we submit that Van Heerden's summary of section 88(3), namely, that it "implies that the consumer had already gone through a debt review which resulted in a debt restructuring order but the consumer failed to comply with the terms of such order", ${ }^{103}$ does not apply in this instance.

\section{The Interplay Between Sections 83 and 85}

In light of the purpose of this note ${ }^{104}$ the interplay between sections 83 and 85 should be considered. A court or the Tribunal in terms of section 83(1) mero motu may take cognisance of the fact that reckless lending has occurred. Where the court or the Tribunal finds that the reckless credit agreement has caused the consumer's over-indebtedness and that the consumer is still over-indebted at the time of the proceedings, ${ }^{105}$ debtalleviation orders in terms of section $83(3)$ (b)(i) and (ii) ${ }^{106}$ will follow. The question arises what the situation would be where reckless credit was involved but where the court fails to take notice of that fact mero motu. As the credit agreement already is before a court no longer is it possible for the consumer to apply for a declaration of reckless credit by a debt counsellor via section $86 .{ }^{107}$

It is submitted that a consumer may utilise the provisions of section 85 and make an allegation that credit was granted recklessly to him or her, in spite of the fact that section 85 makes no provision for such an allegation. There are a number of arguments to substantiate our point of view. However, suffice it to say that in terms of section 85(a), read with section 86(7), a debt counsellor may make recommendations to the court in connection with reckless credit. ${ }^{108}$ Therefore, it may be argued that the legislature intended reckless credit to be included in the context of section 85 .

$102 \mathrm{~S} 88(3)(\mathrm{b})(\mathrm{i})$ read with s 88(1)(a).

1032013 De Jure 968 at 977.

104 See par 1.

105 S 83(3)(a).

106 See Van Heerden in Scholtz (ed) par 11.5.7.2 for an exposition of these orders.

107 S 86(6)(b) provides that a consumer who has applied for debt review in terms of s 86(1), may also seek a declaration of reckless credit, where any of the consumer's credit agreements appear to be reckless.

$108 \mathrm{~S} 86(7)(\mathrm{c})(\mathrm{i})$ provides that a debt counsellor may issue a proposal recommending that the Magistrate's Court inter alia makes an order that one or more of the consumer's credit agreements be declared to be reckless credit. 


\section{Conclusions and Final Remarks}

Binns-Ward J's dictum in Kallides seems to contradict a remark he made with reference to section 85 two paragraphs earlier in the judgment, ${ }^{109}$ namely that " $[\mathrm{t}]$ he wording of the provision ... has a wide import". We submit that the judge's latter remark is supported by the fact that the provision in various instances can serve as an access portal to the Chapter 4 Part D NCA debt relief measures. ${ }^{110}$ The remark is further substantiated by the observation in Seyffert that the dictum in Kallides is too absolute and loses sight of the courts' discretion in terms of section $85^{111}$ and by the fact that the legislature intends to amend section 85 to empower a court to invoke the section's provisions where "it appears to the court that the consumer ... is over-indebted". 112

Therefore, it is our opinion that Van Heerden's submission, ${ }^{113}$ that "the scope for application of section 85 is of necessity confined to those instances where there was no prior debt review application before enforcement of a credit agreement" and that "[i]t is thus [only] a consumer who did not or was unable to access the voluntary debt review process under section 86 before delivery of a section 129(1)(a)-notice who is afforded locus standi to invoke the provisions of section 85 " is too narrow. We are of the opinion that no debt situation in which the

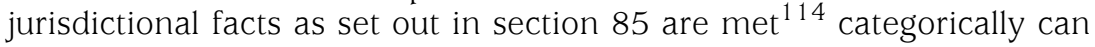
be excluded from the section's possible application.

Accordingly, we submit that, at a minimum, circumstances resorting under sections 86(2), 86(10) (read with s 86(11)), 88(3) and 83 all qualify as instances where section 85 could be applied. From a debt-relief perspective and having regard to one of the main aims of the NCA, namely, to protect the consumer, which inter alia is achieved by "providing mechanisms for resolving of over-indebtedness", 115 the wide ambit of section 85 is to be welcomed. The provision allows a consumer to request the court for the inclusion in debt review of a debt that otherwise could have been excluded from the ambit of the debt-review process and therefore, in most instances, serves as the consumer's last opportunity to access the Chapter 4 Part D debt relief.

We concede that in some instances section 85 will give rise to a measure of circularity, but that it is unavoidable. We also agree with Binns-Ward J ${ }^{116}$ that "[i]t was not the intention of the legislature that the machinery of the Act be used to provide a basis for consumers to wilfully

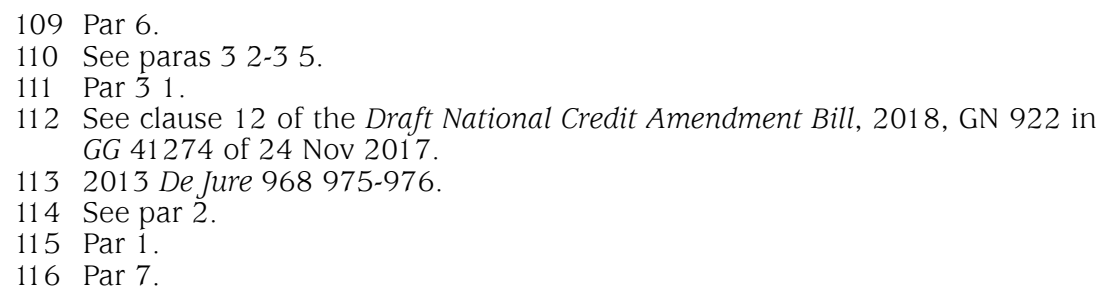


or negligently delay, or unreasonably thwart the enforcement by credit providers of their contractual rights". Van Heerden ${ }^{117}$ submits that the purpose of section 85 is to act as an "abuse-filter"

"to ensure that a consumer (who may or may not be actually over-indebted and who merely wants to delay enforcement) does not abuse his failure to voluntary apply for debt review to perpetuate and compound delay of enforcement by attempting, at a later stage, to access the debt review process again in circumstances where it is clear that he is not entitled to debt relief especially if such disentitlement is based on the fact that he is so overindebted that debt review will not cure his debt problem."

We submit that the court's discretion in terms of section $85^{118}$ acts as the "abuse filter", the safety net to prevent that against which Binns-Ward J cautioned. 